\title{
A Hypothetical Comparison between Event Marketing and Conventional Advertising
}

\author{
Husna Ara ${ }^{1}$, Nafish Sarwar ${ }^{2}$, Mashruha Zabeen ${ }^{3}$ \\ ${ }_{1,2,3}$ (Department of Business Administration, East West University, Dhaka, Bangladesh)
}

\begin{abstract}
The contemporary marketers all over the world are shifting their centre of attention into event marketing due to its intense reputation as a mode of promotion. However, the efficiency of event marketing as a promotional tool over the common advertising practices is yet to be measured. Hence, this article provides a hypothetical analysis via a two-sample proportionate test to measure the effectiveness of event marketing over the usual marketing promotion. The result evidently exhibits that; event marketing is relatively more effective mode of promotion compared to other conventional methods of advertising for developing goodwill, building customer-company relationship and ensuring further re-purchasing tendency.
\end{abstract}

Keywords: Event Marketing; Hypothetical Analysis; Two Sample Proportionate Test

\section{INTRODUCTION}

Schmitt (1) defined event marketing as a tool for experiential marketing that focuses on consumer experiences, and treats emotionally and rationally driven consumption as a holistic experiences that often involve sensory, emotional, cognitive, behavioral and relational values that replace functional values.

Publicity is one aspect of public relation which is more focused on corporate image and controlled by the media, while advertising is more focused on product image and controlled by the sponsor (2). According to Desmet (3), "Creating differential advantage through emotional benefits is one of the keys to market success". Hence, from the definition provided by Schmitt (1) it can be easily claimed that event marketing is supposed to play an important role in the filed of publicity and advertising since, during recent years focus has been on the consumer as an emotionally acting consumer.

The purpose of this study is to examine the effectiveness of event marketing over existing conventional marketing tools. A definitive description of event marketing is provided, along with a literature review about the trends in event marketing. Following the literature review, the research methodology and results of the study are presented. Besides, scope of future research is also discussed at the conclusion.

\section{LITERATURE REVIEW}

Contemporary marketers are continuously facing the challenge that the consumers are less and less responsive to the traditional advertising (4). Hence, they are constantly looking for new marketing communication tools, which have led to a growth in the concept of event marketing. As a component of contemporary promotions mix, event marketing is regarded as an important and promising tool (5). Currently, more than $96 \%$ of the U.S. corporations include event marketing in their promotional strategies (6), and it is estimated that the $22 \%$ of total marketing communications budgets are dedicated to event-related sponsorship activities (7).

However, the concept of event marketing is still very new for many companies and they are very unclear about assessing the effects of an event sponsorship activity and uncertain about how it can be measured (8). Hence, the same research group (9) constructed and tested competing models to examine the relationship among event attendees, sponsorship, community involvement, and the title sponsor's brand with respect to purchase intentions with an on-site study at a sponsored event. At the same time Martensen along with other researchers (10) provided an empirical evidence of a model to asses the effectiveness of event marketing, except for the model can be used only to give directions for how an event should be designed to create positive brand attitude and buying intention. However, no comparative analysis with the existent conventional promotional tools was drawn by either these models. Hence, the purpose of this study aimed to examine the effectiveness of event marketing over existing conventional marketing tools.

\section{METHODOLOGY}

The purpose of this research is to examine the efficiency of event marketing over accessible traditional advertising tools. Hence, a comprehensive literature survey was carried out to identify the relationship between conventional marketing promotion, event marketing and strategic brand management. Based on that literature review, two different sets of questionnaires and sample were designed. 


\section{Questionnaires:}

Based on the literature survey, two different sets of self-administered questionnaires were developed to conduct a proportionate analysis. One set of questionnaire inquired about the effectiveness of conventional marketing promotion while the other set inquired about the effectiveness of event marketing. Both the questionnaires consisted of 10 different questions in 5-point [1.Strongly agree, 2.Disagree, 3.Neutral, 4.Agree, 5.Strongly agree] scale. A rating of 4 and above was considered as a positive response.

A total of 100 questionnaires were distributed and among those 80 were considered suitable for analysis; the other 20 questionnaires could not be considered due to incomplete response. Hence, the overall response rate was $80 \%$.

\section{Sample:}

The proportionate analysis was conducted on two separate but homogenous groups which were chosen on a judgmental sampling method. The target respondents were undergraduate and graduate business students who possess necessary idea about conventional marketing promotion, event marketing and branding and have been exposed to such practices.

Among the earlier mentioned 80 questionnaires, 33 of those were collected from the group that was inquired only about the effectiveness of event marketing; while the remaining 47 questionnaires were collected from group that was inquired only about the effectiveness of conventional marketing promotion.

\section{RESULTS AND DISCUSSIONS}

The results and discussion of the two sample proportionate study is discussed hereafter in four different sections. First the demographic profile of the respondents is presented, followed by the list of hypotheses and survey result; and lastly the proportionate analysis.

The following table exhibits the demographic profile of the respondents participated in the survey. The income group or education is not mentioned in the table, as all the participants were undergraduate and graduate business students.

Table-1: Demographic Profile

\begin{tabular}{|c|c|c|c|c|c|}
\hline \multicolumn{3}{|c|}{ General Marketing } & \multicolumn{3}{|c|}{ Event Marketing } \\
\hline $\begin{array}{l}\text { Age: } \\
\text { Below 20: } \\
\text { 20-to- 22: } \\
\text { Above 22: }\end{array}$ & $\begin{array}{l}14 \\
19 \\
14\end{array}$ & $\begin{array}{l}\text { Percentage: } \\
30 \% \\
40 \% \\
30 \%\end{array}$ & $\begin{array}{l}\text { Age: } \\
\text { Below 20: } \\
\text { 20-to- 22: } \\
\text { Above 22: }\end{array}$ & $\begin{array}{l}8 \\
17 \\
8\end{array}$ & $\begin{array}{l}\text { Percentage: } \\
25 \% \\
50 \% \\
25 \%\end{array}$ \\
\hline Total: & 47 & $100 \%$ & Total: & 33 & $100 \%$ \\
\hline $\begin{array}{l}\text { Gender: } \\
\text { Male: } \\
\text { Female: }\end{array}$ & $\begin{array}{l}28 \\
19 \\
\end{array}$ & $\begin{array}{l}\text { Percentage: } \\
60 \% \\
40 \% \\
\end{array}$ & $\begin{array}{l}\text { Gender: } \\
\text { Male: } \\
\text { Female: }\end{array}$ & $\begin{array}{l}22 \\
11 \\
\end{array}$ & $\begin{array}{l}\text { Percentage: } \\
67 \% \\
33 \% \\
\end{array}$ \\
\hline Total: & 47 & $100 \%$ & Total: & 33 & $100 \%$ \\
\hline
\end{tabular}

Ten different hypotheses were constructed from the survey questionnaire, among which eight were selected for analysis. The other two could not be considered for analysis, as they didn't appear with suitable parameters. However, the questionnaires consisted ten different questions, later among those two questions were rejected for hypothesis building due to above mentioned reason. The hypotheses are listed in the following table [Table-2].

Table-2: List of Hypotheses

\begin{tabular}{|c|l|}
\hline Hypothesis Number & Null-Hypothesis \\
\hline Hypothesis 1 & Advertising can create better brand awareness while compared to event marketing \\
\hline Hypothesis 2 & Advertising can develop favorable product image compared to event marketing \\
\hline Hypothesis 3 & Advertising can develop positive goodwill while compared to event marketing \\
\hline Hypothesis 4 & Advertising is a better way to develop customer relationship than event marketing \\
\hline Hypothesis 5 & Advertising can develop higher re-purchasing tendency than event marketing \\
\hline Hypothesis 6 & Advertising can enhance brand loyalty while compared to event marketing \\
\hline Hypothesis 7 & Advertising can develop favorable customer experience than event marketing \\
\hline Hypothesis 8 & Advertising can effectively reach mass audience compared to event marketing \\
\hline
\end{tabular}

Both the questionnaires consisted of 10 different questions in 5-point [1.Strongly agree, 2.Disagree, 3.Neutral, 4.Agree, 5.Strongly agree] scale. From these 10 questions, 8 questions were selected for hypotheses building (as mentioned before, the other two did not exhibited suitable parameters for analysis). A rating of 4 and above was considered as a positive response. The following results were found from the survey analysis, which are exhibited in Table-3. 
Table-3: Survey Result

\begin{tabular}{|c|c|c|c|c|c|c|c|c|}
\hline \multicolumn{9}{|c|}{ Advertising } \\
\hline $\begin{array}{c}\text { Hypothesis } \\
\text { Number \# }\end{array}$ & $\begin{array}{l}\text { Strongly } \\
\text { Disagree }\end{array}$ & Disagree & Neutral & Agree & $\begin{array}{c}\text { Strongly } \\
\text { Agree }\end{array}$ & Total & $\begin{array}{c}\text { More than } \\
\text { Neutral }\end{array}$ & Ratio-1 \\
\hline Hypothesis 1 & 0 & 0 & 3 & 26 & 18 & 47 & 44 & $93.6 \%$ \\
\hline Hypothesis 2 & 0 & 0 & 5 & 30 & 12 & 47 & 42 & $89.3 \%$ \\
\hline Hypothesis 3 & 0 & 5 & 12 & 21 & 9 & 47 & 30 & $63.8 \%$ \\
\hline Hypothesis 4 & 0 & 5 & 6 & 22 & 14 & 47 & 36 & $76.6 \%$ \\
\hline Hypothesis 5 & 6 & 14 & 11 & 12 & 4 & 47 & 16 & $34.0 \%$ \\
\hline Hypothesis 6 & 1 & 14 & 13 & 13 & 6 & 47 & 19 & $40.4 \%$ \\
\hline Hypothesis 7 & 3 & 11 & 11 & 19 & 3 & 47 & 22 & $46.8 \%$ \\
\hline Hypothesis 8 & 0 & 2 & 2 & 19 & 24 & 47 & 43 & $91.5 \%$ \\
\hline \multicolumn{9}{|c|}{ Event Marketing } \\
\hline $\begin{array}{c}\text { Hypothesis } \\
\text { Number \# }\end{array}$ & $\begin{array}{l}\text { Strongly } \\
\text { Disagree }\end{array}$ & Disagree & Neutral & Agree & $\begin{array}{l}\text { Strongly } \\
\text { Agree }\end{array}$ & Total & $\begin{array}{c}\text { More than } \\
\text { Neutral }\end{array}$ & Ratio-2 \\
\hline Hypothesis 1 & 0 & 1 & 1 & 23 & 8 & 33 & 31 & $94.0 \%$ \\
\hline Hypothesis 2 & 0 & 1 & 4 & 17 & 11 & 33 & 28 & $84.8 \%$ \\
\hline Hypothesis 3 & 0 & 0 & 4 & 17 & 12 & 33 & 29 & $87.9 \%$ \\
\hline Hypothesis 4 & 1 & 3 & 11 & 14 & 4 & 33 & 18 & $54.5 \%$ \\
\hline Hypothesis 5 & 1 & 6 & 10 & 12 & 4 & 33 & 16 & $48.5 \%$ \\
\hline Hypothesis 6 & 0 & 4 & 14 & 9 & 6 & 33 & 15 & $45.5 \%$ \\
\hline Hypothesis 7 & 0 & 2 & 4 & 21 & 6 & 33 & 27 & $81.8 \%$ \\
\hline Hypothesis 8 & 3 & 11 & 7 & 7 & 5 & 33 & 12 & $36.4 \%$ \\
\hline
\end{tabular}

From the analysis mentioned above the following results were concluded. Though with advertising a mass audience can be reached with compared to event marketing [Hypothesis 9: 100\% confidence], but Event marketing can develop better goodwill [Hypothesis 4: 98.40\% confidence], can create better customer company relationship [Hypothesis 5: $96.25 \%$ confidence], can extract more re-purchasing [Hypothesis 6: 80.64\% confidence] and provides a better customer experience [Hypothesis 8: 99.84\% confidence] in comparison to advertising. The analysis is given on the following table [Table-4].

Table-4: Two Sample Proportionate Analysis

\begin{tabular}{|c|c|c|c|c|c|c|c|}
\hline $\begin{array}{l}\text { Hypothesis } \\
\text { Number }\end{array}$ & Ratio 1 & Ratio 2 & $\begin{array}{l}\text { "Pooled" - } \\
\text { Proportion }\end{array}$ & $\begin{array}{l}\text { Standard } \\
\text { Error }\end{array}$ & $\begin{array}{l}\mathrm{Z}-\text { Test } \\
\text { Statistic }\end{array}$ & $\begin{array}{l}\text { The P- } \\
\text { Value }\end{array}$ & $\begin{array}{l}\text { Confidence } \\
\text { Level (1-P) }\end{array}$ \\
\hline $\begin{array}{c}\text { Hypothesis - } \\
1\end{array}$ & $93.6 \%$ & $94.0 \%$ & 0.9375 & 0.055 & -0.073 & 1.058 & $-5.8 \%$ \\
\hline $\begin{array}{c}\text { Hypothesis - } \\
2\end{array}$ & $89.3 \%$ & $84.8 \%$ & 0.8750 & 0.075 & 0.60 & 0.548 & $+45.15 \%$ \\
\hline $\begin{array}{c}\text { Hypothesis - } \\
3 \\
\end{array}$ & $63.8 \%$ & $87.9 \%$ & 0.7375 & 0.1 & -2.41 & 1.984 & $-98.40 \%$ \\
\hline $\begin{array}{c}\text { Hypothesis - } \\
4\end{array}$ & $76.6 \%$ & $54.5 \%$ & 0.675 & 0.106 & -2.08 & 1.962 & $-96.25 \%$ \\
\hline $\begin{array}{c}\text { Hypothesis - } \\
5\end{array}$ & $34.0 \%$ & $48.5 \%$ & 0.4 & 0.111 & -1.30 & 1.806 & $-80.64 \%$ \\
\hline $\begin{array}{c}\text { Hypothesis - } \\
6\end{array}$ & $40.4 \%$ & $45.5 \%$ & 0.425 & 0.112 & -0.46 & 1.354 & $-35.45 \%$ \\
\hline $\begin{array}{c}\text { Hypothesis - } \\
7\end{array}$ & $46.8 \%$ & $81.8 \%$ & 0.6125 & 0.111 & -3.16 & 1.998 & $-99.84 \%$ \\
\hline $\begin{array}{c}\text { Hypothesis - } \\
8 \\
\end{array}$ & $91.5 \%$ & $36.4 \%$ & 0.6875 & 0.105 & 5.24 & 0 & $+100 \%$ \\
\hline
\end{tabular}




\section{CONCLUSION}

This work was carried out with an intention to help the marketers to understand the effectiveness of event marketing. Nevertheless, there are few limitations of this study. This research was a two sample proportionate analysis which was conducted only once during the month of December 2013. Which means the findings might change with the evaluation criteria of the participants. Future research could expand and also be repeated at regular intervals to monitor changes, following the same methodology.

\section{REFERENCES}

[1] Schmitt B. H. (1999) Experiential Marketing. New York: The Free Press, P.26

[2] Keith J. Tuckwell (2009) "Canadian Advertising in Action" Pearson Education Canada Inc. C.14, P.6-8

[3] Desmet, P. M. (2005) Seminar notes from a seminar on Measuring and Understanding Product Emotions he taught at Copenhagen Business School, October 13, 2005. Copenhagen, Denmark: Centre for Marketing Communication, Department of Marketing, Copenhagen Business School

[4] Belch, G. E., and M. A. Belch. (2007) Advertising and Promotion: An Integrated Marketing Communications Perspective, 7th Ed New York: McGraw-Hill/Irwin, P.12

[5] Gupta, S. (2003) "Event Marketing: Issues and Challenges" IIMB Management Review 15, 2: 87-96

[6] MPI FOUNDATION. (2005) "Fourth Annual Trends Study, Event- View '05/'06." Press: July 11 [URL: http://www.gpjco.com]

[7] MPI FOUNDATION. (2004) "AS Events Unfold: Event Trends 2004" The George P Johnson Company Report on the Changing Role of Events in Corporate America's Marketing Mix: [URL: http:// www.mpiweb.org]

[8] Sneath, J. Z., R. Z. Finney, and A. G. Close. (2005) "An IMC Approach to Event Marketing: The Effects of Sponsorship and Experience on Customer Attitudes" Journal of Advertising Research: 373-381

[9] Close, A. G., R. Z. Finney, R. Z. Lacey, and J. Z. Sneath (2006) "Engaging the Consumer through Event Marketing: Linking Attendees with the Sponsor, Community, and Brand" Journal of Advertising Research: 420-433

[10] Martensen, A., L. Gronholdt, L. Bendtsen, and M. J. Jensen. (2007) "Application of a Model for the Effectiveness of Event Marketing" Journal of Advertising Research: 283-301 